\title{
Librarians against fake news: a systematic literature review of library practices (Jan. 2018-Sept. 2020)
}

\begin{abstract}
This study's purpose is to systematically review the literature to identify the most recent library practices against fake news. Libraries are perceived as an important player against the fake news phenomenon. However, this role is often cornered in a positive self-perception of the work of librarians. This article investigates the tangible practices of libraries, discusses their efficiency, and provides a categorization of those practices. It was performed a systematic literature review of the last three years to retrieve the most recent library practices. After the extraction, with a final set of 27 documents, a multi-step qualitative analysis and a categorization were developed. Findings show most studies emphasize academic libraries practices and are mainly focused on information literacy instruction. The current debate is around strategies that intend to reiterate an authority-based source evaluation versus the challenge to recognize an emotional-based reaction to fake news in a post-truth world, and the need to scout libraries' new routes.
\end{abstract}

Keywords Fake News, Misinformation, Post-truth, Librarians, Library Practices, Systematic Literature Review

\section{Introduction}

In mid-October 2020, during this article preparation, a Times investigation disclosed a «Russian disinformation campaign designed to undermine and spread fear about the Oxford University coronavirus vaccine». The main argument used was that the vaccine «could turn people into monkeys because it uses a chimpanzee virus as a vector» (Rana \& O’Neill, 2020). Although this seems unrealistic, social media could easily turn this campaign into an efficient mean of disinformation, and it would be certainly shared and read all over the world.

Beyond health issues, fake news is a serious menace to democratic societies, as they disrupt citizens' electoral capacity and the truthful information needed to vote, ultimately revealing deeper issues: «a crisis of truth is first and foremost a crisis of trust, signaling a sociopolitical breakdown even before an epistemic one» (Cosentino, 2020, pp. 142-143). This assumption is shared by many stakeholders, such as political, educational and media actors, who believe that this phenomenon intensify structural problems of the information environment, like inequalities on information access or the ability to one fully understand new or complex pieces of information.

Above all, fake news is a serious threat to information ecosystems, as truth is no longer related to authority, expertise or real facts, but to interpretation, perception, emotions 
and sentiments (Cooke, 2018). Post-truth arises as a new setting and a new challenge with a global effect (Cosentino, 2020; Lor, 2018; Peters et al., 2018). Are librarians' ready to intervene in patrons' cognitive sphere? To address this subject, new interdisciplinary connections need to be found, for example between Psychology, Media, and LIS (Library and Information Science) studies (Greifeneder et al., 2021).

The key elements for a fake news definition are the intention to mislead, falsity and bias. The sub-elements or properties related with the intention to mislead and/or bias are omission of information, decontextualized content and misleading headlines or clickbait (Lim, 2020). Lim defines fake news as «intentionally misleading and biased representational information for the benefit of the message sender, which contains false information, with or without a blend of one or more components of omitted important information, a decontextualized content, misleading headlines or clickbait» (Lim, 2020, pp. 2-3). Moreover, fake news is a symptom of greater problems, like politicization and weaponization of information, traditional media crisis, and technological incapacity to control the spread of misinformation (Zimdars \& McLeod, 2020).

Despite the historical roots of fake news and the recognition that it's not an entirely new phenomenon (Barclay, 2018), one cannot doubt about the emergence of a different information environment and behavior known as post-truth: "The overconsumption of information fuelled by the internet has produced a so-called "post-truth" society in which people consume information that reaffirms their pre-existing beliefs and ideologies rather than attempting the difficult task of identifying the truth» (De Paor \& Heravi, 2020, p. 1). Fake news is «a calling card of the post- truth condition, whereby the contesting parties accuse each other of imposing the wrong conceptual framework for telling what is true and false» (Fuller, 2018, p. 185). More, «post-truth amounts to a form of ideological supremacy, whereby its practitioners are trying to compel someone to believe in something whether there is good evidence for it or not. And this is a recipe for political domination» (McIntyre, 2018, p. 13).

After the 2016 U.S. presidential election, the theme of fake news gathered a vibrant interest of the scientific community, namely LIS and Media researchers and practitioners (Anderson, 2017; Batchelor, 2017; Affelt, 2019; Sullivan, 2019a). Along the development and world-wide expansion of social media, the new information ecosystem arose as a strong competitor of the mediating position of the traditional press, even though that same press was early seduced by the democratizing potential of massproduced content. Later, the same traditional press developed numerous fact-checking efforts, seeking to regain the mediating control of information processes. Yet, there was already an almost definitive breach of authority: «The rise of social media has of course facilitated this informational free-for-all. With fact and opinion now presented side by side on the Internet, who knows what to believe anymore?» (McIntyre, 2018, p. 87).

Libraries have also experienced a phenomenon of increasing disintermediation, with the massive availability of information from a variety of sources, also undermining their authority and questioning their usefulness in an apparently free digital world. These authority ruptures are part of a larger societal change, affecting religious, educational or science expertise spheres (Elías, 2019; Fuller, 2018). Truth is no longer a value itself, nor the most relevant in the opinion, ideology, and subjective universes (Lopez-Borrull et al., 2018). In the end, « Post-truth is not about reality; it is about the way that humans react to reality (McIntyre, 2018, p. 172). 
Every mediation seems to be at stake and libraries are also strongly affected. As endorsed by ALA: «Libraries are singular in their mission to provide all people with the unbiased and relevant information and essential services that drive opportunity and progress. The role they play in preserving our free and democratic society is unique, and therefore libraries are essential to existing and new national policies» $(2015$, p. 1). Libraries claim to be of the last safe places of open and democratic societies and librarians call out their neutral duties - «strictly committed to neutrality and an unbiased stance regarding collection, access and service» (IFLA, 2012) -, even if it may seem a contradiction. From traditional gatekeepers of the information world, a role already lost, librarians claim now an educator role ((De Paor \& Heravi, 2020). However, could we be certain that «information professionals and librarians have positioned themselves at the front lines of the information war» (De Paor \& Heravi, 2020, p. 5)?

Fake news related issues encompasses the democratic processes and the participation of libraries in those processes (Yerbury \& Henninger, 2018). Librarians cannot be, as Buschman argues, «neutral information doctors prescribing a mere method, but interventionists in the media ecology for democratic purposes. It is not a simple one-toone correspondence of good information equals better democracy (...) it is the signals we send with our spaces and services (physical and virtual) that are important. Our accounts show that democratic life grows from spaces that people want to choose and make their own» $(2019$, p. 221). In fact, neutrality is jeopardized in face of a social and political threat: «Libraries will also need to revisit and re-evaluate their position of neutrality regarding information access and collection development to reflect their strong opposition to fake news» (De Paor \& Heravi, 2020, p. 6). Therefore, libraries' efforts to counteract fake news are only beginnings: «Libraries help to counter fake news both through specific educative actions aimed at it and by being broadly educative institutions with a coherent notion of their role and relationship to informational discernment in democratic society» (Buschman, 2019, p. 222).

Libraries' answers to the 'alternative facts' were diverse, calling out heterogeneous strategies and methods. The main response channel was information literacy, as a comprehensive strategy developed within libraries' instruction in the past decades (Agosto, 2018; Dalkir \& Katz, 2020). CILIP (UK) correlated information literacy, democracy and civic engagement: «In a global environment where 'fake news' has become a recognised term, an ability to display critical judgement about multiple information sources, particularly online, is crucial (...) literacy helps to reach views about the reliability and authority of information sources. In these ways too, information literacy reinforces democracy and civic engagement» (The CILIP Information Literacy Group, 2018, p. 4). In another perspective, a European Commission study also recommended the promotion of «media and information literacy to counter disinformation and help users navigate the digital media environment» as one of the main pillars of responses and actions towards disinformation. However, in this study, libraries are only mentioned once, as partners of schools in «integrating critical media literacy into the core literacies guaranteed to all schoolchildren in Europe, with formal status in national school curricula» (European Commission, 2018, pp. 5; 27).

Several studies refer to information and news literacy and correlate these issues with the ACRL Information Literacy Framework (Association of College and Research Libraries, 2016). One study conducted in Pakistan claimed the possibility of adapting the Framework to a news literacy skillset, and found that «information professionals need to upgrade their news literacy skills through self-learning approach to play an active role in the fight against fake news phenomenon» (Ameen \& Naeem, 2020, p. 11). 
Some authors have strongly criticized a positive self-perception of libraries' abilities to fight fake news, but LIS field had scarcely studied the impact of information literacy and other strategies. Sullivan is one of these critics, claiming that «The most pressing problem with LIS solutions to the problem of misinformation is that they remain untested. Responding to the problems of fake news, LIS authors have made testable claims, but these are presented as statements rather than questions (...) Even when some have sought to measure impact, they have demonstrated a need that information literacy is believed to be able to meet, rather than the actual impact of literacy in meeting that need» (Sullivan, 2019c, p. 2).

Trying to understand libraries' position regarding the fake news phenomenon, this article intends to carry out a systematic review of the literature to identify library practices against fake news. Libraries are mainly perceived as an important player against the fake news phenomenon. However, this role is often cornered in a positive self-perception of the work of librarians. It is important to analyze the tangible practices of libraries, discuss their efficiency, and provide a categorization of those practices. This article outlines practices against fake news, helps to disseminate these strategies and methods, and ultimately provide insights to improve them.

Based on the identified research challenges, the study addresses the following research questions:

RQ1: Since 2018, what were the strategies and methods employed by librarians to fight against fake news?

\section{RQ2: Is it possible to obtain a categorization of libraries practices?}

This paper includes a research methodology section, explaining the procedures of data extraction and the final dataset analysis. The findings section contains the qualitative analysis and the categorization obtained through the analysis of the dataset. The conclusion intends to answer the research questions of the study. The final references list includes not only the literature analyzed in the findings' section, but also other background sources used for a comprehensive acknowledgement of the subject.

\section{Research methodology}

To properly answer RQ1 and obtain the necessary data for RQ2, a systematic literature review was performed, regarding scientific publications from 2018, 2019 and 2020, until September $30^{\text {th }}$. A literature review reflects «the selection of available documents (both published and unpublished) on the topic, which contain information, ideas, data and evidence written from a particular standpoint to fulfil certain aims or express certain views on the nature of the topic and how it is to be investigated, and the effective evaluation of these documents in relation to the research being proposed» (Hart, 1998, p. 13).

A systematic literature review is a «means of identifying, evaluating and interpreting all available research relevant to a particular research question, or topic area, or phenomenon of interest» (Kitchenham, 2004, p. 1) and a «comprehensive search approach with limited bias» (Stapleton et al., 2020, p. 1). Following PRISMA (Preferred Reporting Items for Systematic Reviews and Meta-Analyses) statement, a «systematic review is a review of a clearly formulated question that uses systematic and explicit methods to identify, select, and critically appraise relevant research, and to collect and 
analyze data from the studies that are included in the review» (Moher et al., 2009, p. 1) and «attempts to collate all empirical evidence that fits pre-specified eligibility criteria to answer a specific research question» (Liberati et al., 2009, p. 2). Performing the literature review in a systematic way allows process transparency and grants research reproducibility, as «a defining characteristic of rationalist systematic review methodology is its insistence on explicit searching strategies» (Dixon-Woods et al., 2006, p. 33).

A systematic literature review implies a study selection criteria «intended to identify those primary studies that provide direct evidence about the research question. In order to reduce the likelihood of bias, selection criteria should be decided during the protocol definition» (Kitchenham, 2004, p. 9). Following RQ1, the main condition was to identify recent studies that report or discuss library practices against fake news. Therefore, the documents' selection was guided by this only purpose, without language, country, type of library or author standpoint biases.

\section{Data extraction}

The systematic retrieval used a combination of search terms encompassing the primary concepts of library/libraries/librarians and fake news. The scope of the literature review was not limited to one area of librarianship or region. The literature was retrieved in September $30^{\text {th }}$, 2020. Table 1 identifies the followed search strategies. The databases chosen were considered primarily for their importance, relevance and quality (Web of Science and Scopus); and secondly, for its relevance within LIS field (LISTA - Library, Information Science \& Technology Abstracts). There were no limitations concerning languages of publication, though the search terms were only used in English.

\begin{tabular}{|c|c|c|}
\hline Database & Search Strategy & Number of results \\
\hline SCOPUS & $\begin{array}{l}\text { TITLE-ABS-KEY ( librar* AND "fake news" ) AND } \\
\text { PUBYEAR > } 2017\end{array}$ & 71 \\
\hline WoS & $\begin{array}{l}\text { TOPIC: (librar* AND "fake news") Timespan: 2018-2020. } \\
\text { Databases: WOS, CCC, DIIDW, KJD, MEDLINE, RSCI, } \\
\text { SCIELO. }\end{array}$ & 45 \\
\hline LISTA & $\begin{array}{l}\text { TI ( librar* AND "fake news" ) OR AB ( librar* AND } \\
\text { "fake news" ) OR SU ( librar* AND "fake news" ) OR } \\
\text { KW ( librar* AND "fake news" ) } \\
\text { Expanders: Apply equivalent subjects } \\
\text { Limiters: Publication Date: 20180101-20201231 } \\
\text { Source Types: Academic Journals } \\
\text { Excluded: Magazines (17) Trade Publications (15) } \\
\text { Reviews (7) }\end{array}$ & 61 \\
\hline
\end{tabular}

\section{Final dataset}

Regarding retrieved literature, a set of methods were used to ensure each piece of literature collected was relevant and contributed meaningfully to this study. A practical screening process was applied to identify relevant literature for inclusion. In fact, «systematic screening is an important, yet time consuming, component of a systematic process to identify relevant sources of evidence» (Stapleton et al., 2020, p. 4).

A total of 177 articles were retrieved and organized in a Microsoft Excel sheet. Following PRISMA information flow diagram (Moher et al., 2009), cleaning of 
duplicates resulted in 90 articles. Also, conference news, book reviews and records without author were excluded. After this step, all the articles' titles and abstracts were read and analyzed to assess their correspondence with the research questions. This assessment excluded 51 articles, resulting in a dataset of 39 results. After the full-text reading, 12 more articles were excluded due to the absence of library practices' explicit information. The qualitative analysis was made with a dataset of 27 articles. All this process is represented through a PRISMA Flow Diagram (Figure 1).

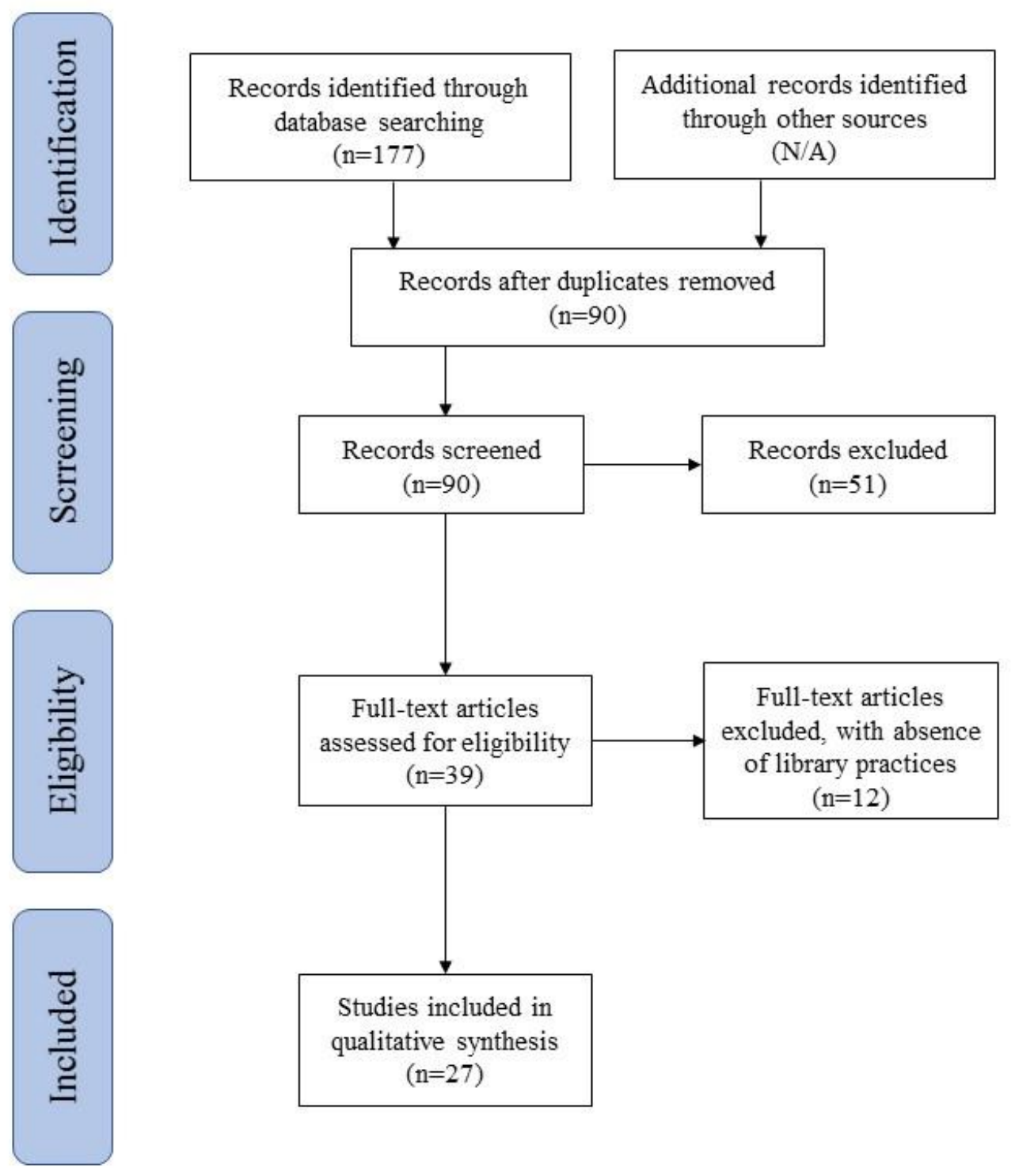

Figure 1 - PRISMA Flow Diagram of Literature Retrieval (adapted from Moher et al., 2009)

In the final dataset (Table 2), there are authors from the USA, Canada, UK, Singapore, Spain, Italy, Pakistan, and other countries, and studies performed all over the world. 
Although it was unintentional, a great background diversity was achieved, being the English language the most used. Still, it's evident an absence of studies from Africa or Latin America, which may be explained by publications' language or database selection issues.

\begin{tabular}{|c|c|c|c|}
\hline ID & Title & Publication & Reference \\
\hline 1 & $\begin{array}{l}\text { Academic library guides for tackling fake } \\
\text { news: a content analysis }\end{array}$ & $\begin{array}{l}\text { Journal of Academic } \\
\text { Librarianship }\end{array}$ & (Lim, 2020) \\
\hline 2 & $\begin{array}{l}\text { Amplify your impact: marketing libraries in } \\
\text { an era of "fake news" }\end{array}$ & $\begin{array}{l}\text { Reference \& User } \\
\text { Services Quarterly }\end{array}$ & $\begin{array}{l}\text { (Eva \& Shea, } \\
\text { 2018) }\end{array}$ \\
\hline 3 & $\begin{array}{l}\text { Breaking the spin cycle: teaching complexity } \\
\text { in the age of fake news }\end{array}$ & $\begin{array}{l}\text { portal: Libraries and the } \\
\text { Academy }\end{array}$ & (Glisson, 2019) \\
\hline 4 & $\begin{array}{l}\text { Con il pretesto delle false notizie: insegnare il } \\
\text { pensiero critico nella scuola italiana a partire } \\
\text { da Carol C. Kuhlthau }\end{array}$ & AIB Studi & (Fontanin, 2018) \\
\hline 5 & $\begin{array}{l}\text { Conflicting authority: using the Trump } \\
\text { administration's responses to the EPA climate } \\
\text { assessment report to teach information } \\
\text { literacy }\end{array}$ & $\begin{array}{l}\text { Reference Services } \\
\text { Review }\end{array}$ & $\begin{array}{l}\text { (Lynch \& } \\
\text { Hunter, 2020) }\end{array}$ \\
\hline 6 & $\begin{array}{l}\text { Democracy, information, and libraries in a } \\
\text { time of post-truth discourse }\end{array}$ & Library Management & (Lor, 2018) \\
\hline 7 & $\begin{array}{l}\text { Educators' perceptions of information literacy } \\
\text { and skills required to spot 'fake news' }\end{array}$ & $\begin{array}{l}\text { Proceedings of the } \\
\text { Association for } \\
\text { Information Science and } \\
\text { Technology }\end{array}$ & $\begin{array}{l}\text { (Delellis \& } \\
\text { Rubin, 2018) }\end{array}$ \\
\hline 8 & $\begin{array}{l}\text { Fake news alerts: teaching news literacy } \\
\text { skills in a meme world }\end{array}$ & Reference Librarian & (Ireland, 2018) \\
\hline 9 & $\begin{array}{l}\text { Fake news, ¿amenaza u oportunidad para los } \\
\text { profesionales de la información y la } \\
\text { documentación? }\end{array}$ & $\begin{array}{l}\text { El Profesional de la } \\
\text { Información }\end{array}$ & $\begin{array}{l}\text { (Lopez-Borrull et } \\
\text { al., 2018) }\end{array}$ \\
\hline 10 & Fake or for real? A fake news workshop & $\begin{array}{l}\text { Reference Services } \\
\text { Review }\end{array}$ & $\begin{array}{l}\text { (Hanz \& } \\
\text { Kingsland, 2020) }\end{array}$ \\
\hline 11 & $\begin{array}{l}\text { Focus on the facts: a news and information } \\
\text { literacy instructional program }\end{array}$ & Reference Librarian & $\begin{array}{l}\text { (Neely-Sardon \& } \\
\text { Tignor, 2018) }\end{array}$ \\
\hline 12 & $\begin{array}{l}\text { Framing Fake News: misinformation and the } \\
\text { ACRL Framework }\end{array}$ & $\begin{array}{l}\text { portal: Libraries and the } \\
\text { Academy }\end{array}$ & $\begin{array}{l}\text { (Faix \& Fyn, } \\
2020)\end{array}$ \\
\hline 13 & $\begin{array}{l}\text { Increasing students' ability to identify fake } \\
\text { news through information literacy education } \\
\text { and content management systems }\end{array}$ & Reference Librarian & (Auberry, 2018) \\
\hline 14 & $\begin{array}{l}\text { Infomediación y posverdad: el papel de las } \\
\text { bibliotecas }\end{array}$ & $\begin{array}{l}\text { El Profesional de la } \\
\text { Información }\end{array}$ & $\begin{array}{l}\text { (Caridad- } \\
\text { Sebastián et al., } \\
2018)\end{array}$ \\
\hline 15 & $\begin{array}{l}\text { Information integrity in the era of fake news: } \\
\text { an experiment using library guidelines to } \\
\text { judge information integrity }\end{array}$ & $\begin{array}{l}\text { Bibliothek Forschung und } \\
\text { Praxis }\end{array}$ & $\begin{array}{l}\text { (Rügenhagen et } \\
\text { al., 2020) }\end{array}$ \\
\hline 16 & $\begin{array}{l}\text { Information literacy and fake news: how the } \\
\text { field of librarianship can help combat the } \\
\text { epidemic of fake news }\end{array}$ & $\begin{array}{l}\text { Journal of Academic } \\
\text { Librarianship }\end{array}$ & $\begin{array}{l}(\text { De Paor \& } \\
\text { Heravi, 2020) }\end{array}$ \\
\hline 17 & $\begin{array}{l}\text { Information literacy in a fake/false news } \\
\text { world: why does it matter and how does it } \\
\text { spread? }\end{array}$ & $\begin{array}{l}\text { International Journal of } \\
\text { Legal Information }\end{array}$ & $\begin{array}{l}\text { (Niedringhaus, } \\
\text { 2018) }\end{array}$ \\
\hline 18 & $\begin{array}{l}\text { Librarians joining the fight against fake news: } \\
\text { a NUS case study }\end{array}$ & $\begin{array}{l}\text { Singapore Journal of } \\
\text { Library \& Information } \\
\text { Management }\end{array}$ & $\begin{array}{l}\text { (Dahri \& } \\
\text { Richard, 2018) }\end{array}$ \\
\hline 19 & $\begin{array}{l}\text { Libraries and fake news: what's the problem? } \\
\text { what's the plan? }\end{array}$ & $\begin{array}{l}\text { Communications in } \\
\text { Information Literacy }\end{array}$ & (Sullivan, 2019a) \\
\hline
\end{tabular}




\begin{tabular}{llll}
\hline 20 & $\begin{array}{l}\text { Lots of questions about 'fake news': how } \\
\text { public libraries have addressed media } \\
\text { literacy, 2016-2018 }\end{array}$ & Public Library Quarterly & $\begin{array}{l}\text { (LaPierre \& } \\
\text { Kitzie, 2019) }\end{array}$ \\
\hline 21 & $\begin{array}{l}\text { Lucha contra la desinformación desde las } \\
\text { bibliotecas universitarias }\end{array}$ & $\begin{array}{l}\text { El Profesional de la } \\
\text { Información }\end{array}$ & $\begin{array}{l}\text { Cardamez- } \\
\text { Algora-Cancho, } \\
\text { 2019) }\end{array}$ \\
\hline 22 & $\begin{array}{l}\text { National library board's public education on } \\
\text { information literacy: teaching citizens to fight } \\
\text { fake news }\end{array}$ & $\begin{array}{l}\text { Singapore Journal of } \\
\text { Library \& Information } \\
\text { Management }\end{array}$ & $\begin{array}{l}\text { (Pek \& Wang, } \\
\text { 2018) }\end{array}$ \\
\hline 23 & $\begin{array}{l}\text { Real or fake? Resources for teaching college } \\
\text { students how to identify fake news }\end{array}$ & $\begin{array}{l}\text { College \& Undergraduate } \\
\text { Libraries }\end{array}$ & $\begin{array}{l}\text { (Musgrove et al., } \\
\text { 2018) }\end{array}$ \\
\hline 24 & $\begin{array}{l}\text { Reflections on fake news, librarians, and } \\
\text { undergraduate research }\end{array}$ & $\begin{array}{l}\text { Reference \& User } \\
\text { Services Quarterly }\end{array}$ & $\begin{array}{l}\text { (Rose-Wiles, } \\
\text { 2018) }\end{array}$ \\
\hline \multirow{2}{*}{25} & $\begin{array}{l}\text { Stop! Don't share that story!: Designing a } \\
\text { pop-up undergraduate workshop on fake } \\
\text { news }\end{array}$ & $\begin{array}{l}\text { Reference Librarian } \\
\text { (Wade \& }\end{array}$ & Hornick, 2018) \\
\hline 26 & $\begin{array}{l}\text { The Covid-19 'infodemic': a new front for } \\
\text { information professionals }\end{array}$ & $\begin{array}{l}\text { Health Information \& } \\
\text { Libraries Journal }\end{array}$ & $\begin{array}{l}\text { (Naeem \& Bhatti, } \\
\text { 2020) }\end{array}$ \\
\hline \multirow{2}{*}{27} & $\begin{array}{l}\text { Why librarians can't fight fake news } \\
\text { Tournal of Librarianship } \\
\text { and Information Science }\end{array}$ & (Sullivan, 2019b) \\
\hline
\end{tabular}

Table 2 - Final set of publications for analysis $(n=27)$

\section{Findings}

Findings show most studies emphasize academic libraries practices and are mainly focused on information literacy instruction. The current debate is around strategies that intend to reiterate an authority-based source evaluation versus the challenge to recognize an emotional-based reaction to fake news in a post-truth world, and the need to scout libraries' new routes.

The analysis' results also suggest a two-fold situation. Most of the library practices could be categorized in a double perspective. On one side, library practices tend to perform task-oriented strategies; on the other side, libraries tend to develop a critical thinking approach. Sometimes they coexist, and the latter is presented as a kind of advance, or improvement, of the first. This duplicity had been already identified by Saunders and Budd: «research suggests that there might be some support for librarians to shift some of their attention from task and process-based topics like searching to more critical thinking skills like evaluating information» (2020, p. 6).

While it was found a large majority of studies within academic setting, especially among higher education libraries, public libraries were only mentioned a few times. In a literature review, the authors found that «while public libraries are currently making concerted efforts to inform and educate their patrons on fake news, collaboration is necessary to ensure that these strategies and efforts are being recognised and acknowledged at a level where progress, development and investment can occur. Public libraries should continue to embrace the topical nature of fake news and collaborate with local schools, organisations and community groups to help reach out to wider audiences» (De Paor \& Heravi, 2020, pp. 6-7).

The recent Covid-19 pandemic, and the subsequent 'infodemic', revealed the strength of fake news and its malicious effect on the information ecosystem. The numbers are dramatic for public health: about half of the population in countries like UK or USA is reporting a misinformed status about the new coronavirus (Naeem \& Bhatti, 2020). Since preliminary studies, perceived as science 'truths', until conspiracy theories, the effect of fake news is devastating. Health science librarians are called out to fight 
against fake news, through library guides, checklists and, most of all, information and media literacy programs (Naeem \& Bhatti, 2020).

Information literacy has been the main answer to fake news. A Canadian experience on information literacy instruction, including a tailored workshop on fake news inspired by the ACRL Framework, was reported. It also presents the results of a game that was played with the workshop participants. The workshop included the following contents: History of fake news; Journalistic and personal bias; The currency, relevance, authority, accuracy and purpose (CRAAP) test; Spotting fake news; Domain names; Advanced search techniques; Wikipedia; 'Fake or for real' game; "How to spot fake news" IFLA infographic (Hanz \& Kingsland, 2020). Libraries' position on issues like authority and source evaluation is considered through an information literacy perspective.

Niedringhaus argues that «Learning how to make a logical argument and how to recognize one when we hear it is critical. We need to empower our students by giving them the tools they need to assess the information they are receiving. They need to be able to assess authority and expertise. They need to understand the difference between correlation and causation» (2018, p. 99). Other study reported a college library information literacy pilot program, consisting on a News Literacy Module, which could be embedded within a course's Learning Management System (LMS), and which uses RADAR (Mandalios, 2013) and the IFLA infographic. Source evaluation is the key against fake news: «rather than labeling each source as fact versus fake, a more productive way of combating the use and sharing of unreliable content would be to effectively evaluate information - in other words, focus on where the information itself comes from, who is producing it, and for what purpose» (Auberry, 2018, p. 181).

Another workshop on fake news is described by Wade and Hornick. In a self-confident perspective - «we knew we had the resources to address the information consumption habits of students at our institution and present to them the skills they need to critically analyze the credibility of what they see online» (2018, p. 188) - the authors explain that the one-hour lesson «explored the structure of online news articles and how social media platforms can introduce bias and diminish a reader's ability to determine accuracy or credibility» (p. 190), with four sections included: headlines, visual literacy, evidence (using fact-checkers), and analysis. Beyond this workshop, the authors also reported a participation in a library guide.

Most of the studies analyzed present information literacy resources for teaching college and university students. This population is vulnerable to fake news as they consume information mainly on social media. A study propose a «combination of understanding the psychological background in believing misinformation, teaching critical thinking skills, and instructing university students in information literacy skills» (Musgrove et al., 2018, p. 244). The use of ACRL Framework is pointed out, as well as LibGuides, CRAAP worksheet, and fact-checking websites. A case study from Singapore reports an information literacy program developed by librarians and media experts partnering to fight against fake news. It was performed firstly a «90-minute face-to-face tutorial packed full of materials that were divided into five main sections: the steps to detect fake news, in-depth evaluation of sources in news stories, evaluating academic sources, reverse image searching and fact-checking social media posts», complemented with a library guide (Dahri \& Richard, 2018, p. 17). Later, the tutorial contents were enlarged to 360 minutes of learning time, including the use of IMVA/IN framework (Independent sources, Multiple sources, Sources who Verify with evidence, Authoritative/Informed sources, Named sources), from Stony Brook Center for News Literacy, to evaluate sources which show up in news stories, and concluding that 
«librarians are more than suited to join the fray against fake news with their skills in information evaluation and the position of libraries as neutral institutions» (Dahri \& Richard, 2018, p. 22).

Regarding fake news, Eva and Shea (2018) argue that academic and public libraries leveraged the issue to market themselves and their information literacy programs. It was an advocacy and public relations opportunity to resell library values and usefulness. It may seem too optimistic to call librarians «the original fact checkers» $(2018$, p. 171) or to exacerbate library readiness to become a solution, as there's no clear evidence (yet) of the impact of these activities among library patrons. Nevertheless, new partnerships arose and maybe a new awareness of the library role could persist: «Librarians and journalists have taken this as a call to arms to help members of the public hone their ability to wade through what is real and what is fabricated» (Eva \& Shea, 2018, p. 171). A closer look to one of the libraries' products exposed some weaknesses. It was performed a content analysis of 21 university library guides to understand librarians' self-perception and their strategies and methods concerning students and fake news. Most of the library guides reveal a checklist approach for fake news detection. However, it's not clear how librarians acknowledge fake news phenomenon. The author has doubts about the checklist method efficacy (binary assessment and a mechanical view of information), suggesting the lateral reading approach. Also, it's suggested that librarians should pursue information evaluation training, adapting new methods for news sources, prioritizing checklists and the click restraints, which implies mastering web search techniques (Lim, 2020).

Among this dataset, other type of libraries is studied. Focusing sixty-five American public libraries and media literacy as a response to fake news recrudescence, the authors seek to contradict the literature hegemony about academic libraries initiatives and pointof-views. Even outside an educational setting: «By promoting news literacy awareness, providing a safe place for engaging in more productive socio-political dialog, and enabling older adults to become more digitally savvy, public libraries are vital to bridging the knowledge gap» (LaPierre \& Kitzie, 2019, p. 429). For improving media literacy skills, 82 percent of the libraries engaged recently in initiatives. Most news literacy initiatives «consisted of panels and partnerships with journalists» (p. 437), including fake news thematic initiatives, a term not mentioned in the survey but reported by librarians. The growing interest of the communities in fake news issues seem to be an advantage to libraries efforts: «It seems likely that the use of such terms trending in the media and creating a buzz in communities helps libraries to promote relevant programs and services» (p. 444). Also, a national library approach against fake news is unique. Describing SURE (Source, Understand, Research, Evaluate) program, information literacy is considered essential to fight online falsehood, providing information evaluation abilities. Due to the particular situation of Singapore - the «majority of Singaporeans (87\%) read their news online, with $63 \%$ obtaining news from social media. Less than half (43\%) turn to print and slightly more than half $(55 \%)$ watch news on TV» (Pek \& Wang, 2018, p. 3) - polls and legislation against this phenomenon have been in development. SURE program is embedded in school and workplace activities, targeting different groups with different strategies, including senior citizens. This Singaporean experience «looks beyond traditional approaches to IL instruction by using games and activities» (p. 8), like a quiz game on the Google Assistant platform called "Real or Fake".

A critical thinking approach is often viewed as a step forward traditional information literacy. Developing a news literacy instruction program for college students, the ACRL 
framework motivated a transformation of an information literacy instruction from a «focus on access and descriptions of various types of sources to a holistic exercise in critical thinking» (Neely-Sardon \& Tignor, 2018, p. 109). This experience used mainly a RADAR infographic and the development of a library guide. In a Spanish study, it is proposed a two-fold action: inclusion of civic issues in information literacy and media literacy programs and the development of thematic guides on fake news phenomenon. Regarding the guides' design, the authors recommend a seven-piece content, including (1) the definition of fake news and related concepts; (2) source evaluation (checklists, like CRAAP or IFLA infographic); (3) fact checking (factcheck.org, Snopes,...); (4) other resources to check pictures or video, like Google Reverse Image Search); (5) dissemination of press subscribed by the library; (6) practical exercises on detecting fake news or acknowledging users' own bubble; (7) librarian support and his/her email or chat (Caridad-Sebastián et al., 2018). Faix \& Fyn tried also to view beyond the authority frame of ACRL Framework, proposing a holistic approach to the misinformation problem and a promotion of critical thinking encompassing other possibilities provided by the other frames. There is «an urgent need for librarians and teachers to update and redesign source evaluation strategies, or to create and use new techniques flexible enough for the fast-evolving misinformation environment» (2020, p. 496). Mentioning an example of one of the other frames, the authors state that "'Searching as Strategic Exploration" specifically mentions the affective dimensions of research, perhaps this frame's biggest shift from the 2000 ACRL Information Literacy Competency Standards for Higher Education, in which emotional response to information was not considered. (...) Believing misinformation is closely connected to confirmation bias and emotion» (Faix \& Fyn, 2020, p. 504). In the end, «Moving from the ACRL Standards to the Framework modeled a professional shift away from a checklist-based approach toward a concept-driven approach to information literacy. This shift followed the evolution of the Internet as it became more interactive and socially driven, requiring more flexibility from teachers and librarians to help students navigate this fast-changing online world» (Faix \& Fyn, 2020, p. 505). With many Spanish examples, another author proposes that critical thinking should be the main part of information literacy instruction and the information professionals must assume their leadership and historical position in the fight against fake news (Lopez-Borrull et al., 2018).

Rose-Wiles highlighted the difficulties of critical thinking instruction, suggesting «a combination of cooperation among librarians, vendors, and publishers in providing carefully curated resources, information-literacy instruction, and training in critical thinking» (Rose-Wiles, 2018, p. 203). This would enable getting undergraduate students to use library resources in a persistent way, although the author recognizes a tension between the users' need for fast answers and the librarians' recommendations for a careful source evaluation. Fake news success may be exactly here: information provision is multiple and instant-like, which aligns perfectly with the desire for rapid research answers.

Definitely contrary to this optimistic stance, Sullivan (2019a) reviewed the libraries' responses to fake news since 2016 until the end of 2018. Many of the documents analyzed in this paper were also reviewed by Sullivan, who noticed that librarians' position about fake news should be taken into account carefully: «Absent an understanding of our all-too-human vulnerability to misinformation, librarians risk characterizing the problem as somehow outside of themselves» (2019a, p. 97), as if librarians weren't also possible victims of the phenomenon. 
Librarians also risk being overconfident about their abilities to counteract fake news, particularly through the information and media literacy instruction: «Where librarians are confident in their opposition to fake news but vague about the precise nature of the problem, solutions lack specificity. Whatever the problem is, information literacy is the answer» (Sullivan, 2019a, p. 98). Sullivan proposes an interdisciplinary research agenda «pertaining to misinformation, biases, and critical thinking» (2019a, p. 105), in which libraries should contribute demonstrating the success of their strategies and methods or partnering with members of the media to develop a set of initiatives against fake news. The author also suggests a reconsideration of research guides and checklists to remove unrealistic recommendations (like reading the About pages), and proposes instruction on lateral reading and on image and video verification. Measuring the impact of library instruction is also urgent.

Sullivan describes LIS literature and other library-based initiatives against fake news in interesting terms, as they reveal «a strong sentiment that librarians have an opportunity, if not duty, to join, if not lead, the fight against fake news, misinformation, disinformation, and the like» (2019b, p. 1147). Although the solutions are somewhat vague, the major problem is the acknowledgement of fake news and misinformation as serious menaces to our minds, with irreversible effects. Sullivan argues that «instead of a reaffirmation of the role librarians can play in combating misinformation, what is needed now is a reassessment of the core assumptions and values that underlie that potential role» (p. 1147). However, a closer look reveals what it seems to be a dead end: «unresolved tensions between the core library values underlying the solutions to the problem of misinformation, on the one hand, and the opposition to more global, technological solutions, on the other (...) On one side, there is intellectual freedom and unrestricted access to information; on the other, the primary library service of selecting, verifying, and controlling collections on behalf of users» (Sullivan, 2019b, p. 1149).

Summarizing LIS solution to misinformation, Sullivan explains that the 'library faith' in quality information believe in the existence of an information gap, but this gap is already filled with misinformation; more, information literacy assume a positive education effect, but there isn't an established correlation between education and protection against misinformation. Sullivan's analysis is quite challenging to the library ethos, calling out naive approaches like some consideration about users' laziness in face of misinformation. It would be easier to proceed with the traditional strategies and methods; however, this is a mental information-processing issue. Three needs should be addressed: «deeper understanding of the problem of misinformation; research on «library strategies and what impact they may have on guarding against or correcting misinformation»; and «engage with and contribute to technological solutions that can assist in identifying unverified or outright false information» (Sullivan, 2019b, pp. 1153-1154).

In other perspective, information literacy scope could be broadened: «Metaliteracy offers a new and contemporary framework that reflects the current digital environment and provides effective approaches that can help prepare individuals for the information age. Librarians should therefore consider reframing and repositioning information literacy at a time where their expertise is being given much attention and their solutions greatly welcomed» (De Paor \& Heravi, 2020, p. 7). A Canadian study found that although more than half of the participants agreed that some fake news content should be included in information literacy curriculum, only a few curricula included one of these segments. Nevertheless, participants perceived a strong overlap between information literacy skills and the skills considered essential to fake news detection, 
specifically «an understanding of how language works (close-reading skills), skepticism/critical disposition, an understanding about how information is produced, an awareness of biases (both internal and external), and the ability to synthesize various sources/perspectives» (Delellis \& Rubin, 2018, p. 786). In a study conducted in a secondary school, fake news are used as a pretext for a larger program (including librarians) of critical thinking training on web information, according to Carol Kuhlthau' guided enquiry model (Fontanin, 2018). Ireland (2018) designed a course called Fact or fake? Learn to tell real information from the scams. She proposes a creative-centric approach: «Making memes and infographics that connect with library users on the same level that fake news does can help turn the tide. Visual information can have a profound impact on a library user and may stay with that person longer than verbal or written guidance» (Ireland, 2018, p. 127).

Librarians seem to acknowledge the cognitive and emotional dimensions of fake news. One study focuses the role of emotions and values in news reading. The information literacy instruction based on sources' authority issues (Association of College and Research Libraries, 2016) is questioned. In this assessment, librarians should understand better the way one process, accept and reject information; they should include in training some social and emotional elements, as post-truth means an emotional response to the reality, more than an authoritative assessment. The focus should be placed on the learners instead of the sources. Therefore, the authors propose the use of IF I APPLY tool, «an acronym which divides source evaluation into two basic steps: the personal evaluative steps (IF I) and the source evaluation steps (APPLY)» and «takes several steps in the right direction by including more learner-centered evaluation techniques» (Lynch \& Hunter, 2020, pp. 210-211). Also questioning the authority issue in ACRL Framework and the checklists approach, Glisson suggests a critical approach to information literacy instruction, concerning a discussion-based approach, with a strong visual composition: «I avoided the temptation to merely deliver an informative lecture on disinformation illustrated by clever slides and instead encouraged student interaction. Students retain information more effectively if they are active participants. The slides were meant to visually introduce an idea and provoke dialogue» $(2019$, p. 477). Lor (2018) integrates libraries' response to fake news as part of a more general response to the threats concerning core values as diversity and inclusion. Critically discussing libraries' responses, the author claims that there are no simple antidotes to fake news. Social and psychological explanations outdate most of libraries strategies and methods. The peripheral role of libraries depicted by Lor underlines the rhetoric claims of librarians on their efficiency combating fake news. Pursuing their long-term constancy and their soft power capabilities, libraries should partner with other players such as educators, journalists and media. Analyzing the concept of information integrity, as the degree in which information is true or honest, it was conducted an experiment in which four library-based guidelines usefulness for measuring information integrity was tested. The focus of this study was on checklists, and six fake news articles from websites were the test set. Even though the authors conclude that those guidelines make users think about the information consumed, the study findings reveal the importance of personal background in modifying the reader perception and the evidence collected to verify information, which explains why three different persons reach different conclusions despite using the same evaluation tools (Rügenhagen et al., 2020).

Beyond a majority of single library or single programs' case studies, a study with 42 Spanish academic libraries revealed that librarians consider that top priorities to improve media literacy skills should be library guides, infographics, literacy instruction 
and tutorials, and social media campaigns. In a practical dimension, when asked about their intentions to implement some of these strategies, only half of the librarians responded in a positive way. Nevertheless, several activities were reported and put into categories, such as: instruction activities (information literacy, information evaluation, digital skills, etc.); dissemination activities (infographic dissemination, social media campaigns); audiovisual activities (Youtube videos on the library channel); and reference activities (library guides, collection-based diffusion). In fact, some of these activities were fake news-oriented but others are general action towards media and information literacy; however, librarians pointed out the need for a better faculty-library collaboration (Martínez-Cardama \& Algora-Cancho, 2019).

Following some of these categories, Table 3 presents a new categorization grounded in the literature analysis. All the main categories intended to represent a principal, but not exclusive, focus: 'Source evaluation' represents strategies focused on the information source; 'Information literacy' represents strategies focused on individual patrons; 'Dissemination' represents strategies focused on library audiences; 'Out-of-IL-box' represents strategies that intend to overcome information literacy weaknesses.

\begin{tabular}{|c|c|c|c|}
\hline \multicolumn{3}{|c|}{ Library practices against fake news } & \multirow{2}{*}{$\begin{array}{l}\text { ID [Table 2] } \\
1 ; 10 ; 11 ; 16 ; 18 ; 23 ; 26\end{array}$} \\
\hline \multirow{5}{*}{$\begin{array}{l}\text { Source } \\
\text { Evaluation }\end{array}$} & \multirow{3}{*}{$\begin{array}{l}\text { Checklist } \\
\text { approach }\end{array}$} & $\begin{array}{l}\text { CRAAP (Currency, Relevance, } \\
\text { Authority, Accuracy, and Purpose) }\end{array}$ & \\
\hline & & $\begin{array}{l}\text { RADAR (Rationale, Authority, Date, } \\
\text { Accuracy, Relevance) }\end{array}$ & $11 ; 13$ \\
\hline & & $\begin{array}{l}\text { IFLA infographic 'How to Spot Fake } \\
\text { News' }\end{array}$ & $1 ; 2 ; 4 ; 9 ; 10 ; 13 ; 21$ \\
\hline & \multirow{2}{*}{$\begin{array}{l}\text { Other } \\
\text { techniques }\end{array}$} & Lateral reading & $1 ; 19$ \\
\hline & & IF I APPLY method & 5 \\
\hline \multirow{3}{*}{$\begin{array}{l}\text { Information } \\
\text { Literacy }\end{array}$} & $\begin{array}{l}\text { Library } \\
\text { materials }\end{array}$ & $\begin{array}{l}\text { Library guides (including fact-checking } \\
\text { resources) }\end{array}$ & $\begin{array}{l}1 ; 2 ; 11 ; 14 ; 15 ; 16 ; 18 \\
20 ; 21 ; 23 ; 25 ; 26\end{array}$ \\
\hline & $\begin{array}{l}\text { Formal } \\
\text { instruction }\end{array}$ & Classroom or online instruction & $\begin{array}{l}2 ; 4 ; 7 ; 9 ; 10 ; 12 ; 13 ; 14 ; 16 ; \\
17 ; 18 ; 21 ; 22 ; 23 ; 24 ; 25 ; 26\end{array}$ \\
\hline & $\begin{array}{l}\text { Other } \\
\text { approaches }\end{array}$ & $\begin{array}{l}\text { Discussion-based approach engaging } \\
\text { critical thinking skills }\end{array}$ & $3 ; 12$ \\
\hline \multirow{4}{*}{ Dissemination } & \multirow[b]{2}{*}{ Audio-visual } & Memes and infographics & $8 ; 22$ \\
\hline & & $\begin{array}{l}\text { Audio-visual activities, like YouTube } \\
\text { videos }\end{array}$ & 21 \\
\hline & Public events & Panels and partnerships with journalists & $2 ; 20$ \\
\hline & Social media & Social media campaigns & $2 ; 21 ; 22$ \\
\hline \multirow{2}{*}{$\begin{array}{l}\text { Out-of-IL- } \\
\text { Box }\end{array}$} & $\begin{array}{l}\text { New and old } \\
\text { partnerships }\end{array}$ & $\begin{array}{l}\text { Partnerships with other players such as } \\
\text { educators, journalists, media, publishers, } \\
\text {.. }\end{array}$ & $6 ; 19 ; 24$ \\
\hline & $\begin{array}{l}\text { Technological } \\
\text { route }\end{array}$ & $\begin{array}{l}\text { Technological solutions to identify false } \\
\text { information }\end{array}$ & 27 \\
\hline
\end{tabular}

Table 3 - Categorization of library practices against fake news, as evidenced in the literature

This outline allows several intersections between categories, not only within the literature reviewed, but in libraries' real practices. A librarian could develop a formal instruction, applying ACRL framework, while using checklists or learner-centered approaches. Or, a librarian may produce a social media campaign using library guides or audio-visual activities. As mentioned before, most of the literature concerns information literacy strategies, as it was the main answer to fake news phenomenon. However, literature reveals that information literacy methods are being called into question, often opening space for alternative strategies or ideas. For that reason, it was 
included a section Out-of-IL-box, as a research hypothesis meaning alternative ways developed by traditional information literacy critics.

\section{Conclusion}

This article intended to carry out a systematic review of the literature to identify the library practices against fake news. After the data extraction, a final set of 27 documents were analyzed, resulting in a new categorization, grounded in the literature and able to create new insights on the subject.

Fake news and post-truth represent a major challenge to libraries. Librarians internalized the call and immediately took their place on the front line against fake news. This attitude of self-confidence has led librarians to fetch their strategies and methods experimented for many years. The literature presents this movement, but also the positions of those who believe that these strategies and methods may no longer be efficient, given that the post-truth implies an emotional and cognitive dimension, which goes far beyond the domain of information search and evaluation skills.

Furthermore, there is not enough evidence of the success of these strategies and methods employed by librarians against fake news. The literature reveals only a few results from empirical studies focused on information behavior change. Most of the articles refer to pilot programs, recommendations and proposals, without assessing the impact of the libraries' efforts, as Sullivan had already pointed out: «It is thus essential to note that both the shortcomings and successes of checklists or other approaches remain theoretical, as there has been little empirical testing of their effectiveness - and none in the context of fake news» (2019a, p. 101). This is an issue that must be revisited, considered, and discussed in future research. Other field that should engage research is the studies concerning public or school libraries, and their initiatives against fake news.

Both research questions were positively answered. Findings show most studies emphasize academic libraries practices and are mainly focused on information literacy instruction. The current debate is around strategies that intend to reiterate an authoritybased source evaluation versus the challenge to recognize an emotional-based reaction to fake news in a post-truth world, and the need to scout libraries' new routes. Clearly, there is a strong need to develop and broaden information literacy strategies and methods, as well as to seek other ways of fighting against fake news.

The main limitation of this study is concerned with the amount of data retrieved and the time needed for a deeper analysis, as this theme is already well documented in LIS literature.

\section{Funding:}

This research did not receive any specific grant from funding agencies in the public, commercial, or not-for-profit sectors. 


\section{References}

Affelt, A. (2019). All That's Not Fit to Print: Fake News and the Call to Action for Librarians and Information Professionals. Emerald.

Agosto, D. E. (Ed.). (2018). Information literacy and libraries in the age of fake news. Libraries Unlimited.

Ameen, K., \& Naeem, S. B. (2020). Demographic differences in the perceived news literacy skills and sharing behavior of information professionals. Information Discovery and Delivery, Ahead of print(Ahead of print), 1-13. https://doi.org/10.1108/IDD-02-2020-0015

American Library Association. (2015). National Policy Agenda for Libraries: Executive Brief. American Library Association. http://www.ala.org/advocacy/sites/ala.org.advocacy/files/content/pdfs/NPAforLib rariesBrief2.pdf

Anderson, R. (2017). Fake news and alternative facts: Five challenges for academic libraries. Insights, 30(2), 4-9. https://doi.org/10.1629/uksg.356

Association of College and Research Libraries. (2016). Framework for Information Literacy for Higher Education. Framework for Information Literacy for Higher Education. http://www.ala.org/acrl/standards/ilframework

Auberry, K. (2018). Increasing students' ability to identify fake news through information literacy education and content management systems. The Reference Librarian, 59(4), 179-187. https://doi.org/10.1080/02763877.2018.1489935

Barclay, D. A. (2018). Fake news, propaganda, and plain old lies: How to find trustworthy information in the digital age. Rowman \& Littlefield.

Batchelor, O. (2017). Getting out the truth: The role of libraries in the fight against fake news. Reference Services Review, 45(2), 143-148. https://doi.org/10.1108/RSR03-2017-0006

Buschman, J. (2019). Good news, bad news, and fake news: Going beyond political literacy to democracy and libraries. Journal of Documentation, 75(1), 213-228. https://doi.org/10.1108/JD-05-2018-0074

Caridad-Sebastián, M., Morales-García, A.-M., Martínez-Cardama, S., \& García-López, F. (2018). Infomediación y posverdad: El papel de las bibliotecas. El Profesional de La Información, 27(4), 891-898. https://doi.org/10.3145/epi.2018.jul.17

Cooke, N. A. (2018). Fake news and alternative facts: Information literacy in a posttruth era. ALA Editions.

Cosentino, G. (2020). Social Media and the Post-Truth World Order: The Global Dynamics of Disinformation. Palgrave Pivot.

Dahri, R. B. M., \& Richard, H. C. Y. (2018). Librarians Joining the Fight Against Fake News: A NUS Case Study. Singapore Journal of Library and Information Management, 47, 15-24. https://www.las.org.sg/wp/sjlim/librarians-joining-thefight-against-fake-news-a-nus-case-study/

Dalkir, K., \& Katz, R. (Eds.). (2020). Navigating Fake News, Alternative Facts, and Misinformation in a Post-Truth World. Information Science Reference. 
De Paor, S., \& Heravi, B. (2020). Information literacy and fake news: How the field of librarianship can help combat the epidemic of fake news. The Journal of Academic Librarianship, 46(5), 102218. https://doi.org/10.1016/j.acalib.2020.102218

Delellis, N. S., \& Rubin, V. L. (2018). Educators' perceptions of information literacy and skills required to spot 'fake news'. Proceedings of the Association for Information Science and Technology, 55(1), 785-787. https://doi.org/10.1002/pra2.2018.14505501116

Dixon-Woods, M., Bonas, S., Booth, A., Jones, D. R., Miller, T., Sutton, A. J., Shaw, R. L., Smith, J. A., \& Young, B. (2006). How can systematic reviews incorporate qualitative research? A critical perspective. Qualitative Research, 6(1), 27-44. https://doi.org/10.1177/1468794106058867

Elías, C. (2019). Science on the Ropes: Decline of Scientific Culture in the Era of Fake News. Springer.

European Commission. (2018). A multi-dimensional approach to disinformation: Report of the independent High level Group on fake news and online disinformation. Publications Office of the European Union. http://dx.doi.org/10.2759/739290

Eva, N., \& Shea, E. (2018). Amplify Your Impact: Marketing Libraries in an Era of "Fake News". Reference \& User Services Quarterly, 57(3), 168-171. http://dx.doi.org/10.5860/rusq.57.3.6599

Faix, A., \& Fyn, A. (2020). Framing Fake News: Misinformation and the ACRL Framework. Portal: Libraries and the Academy, 20(3), 496-508. https://doi.org/10.1353/pla.2020.0027

Fontanin, M. (2018). Con il pretesto delle false notizie: Insegnare il pensiero critico nella scuola italiana a partire da Carol C. Kuhlthau. AIB Studi, 58(2), 267-283. http://dx.doi.org/10.2426/aibstudi-11825

Fuller, S. (2018). Post- Truth: Knowledge as a Power Game. Anthem Press.

Glisson, L. (2019). Breaking the Spin Cycle: Teaching Complexity in the Age of Fake News. Portal: Libraries and the Academy, 19(3), 461-484. https://doi.org/10.1353/pla.2019.0027.

Greifeneder, R., Jaffé, M. E., Newman, E. J., \& Schwarz, N. (Eds.). (2021). The psychology of fake news: Accepting, sharing, and correcting misinformation. Routledge.

Hanz, K., \& Kingsland, E. S. (2020). Fake or for real? A fake news workshop. Reference Services Review, 48(1), 91-112. https://doi.org/10.1108/RSR-09-20190064

Hart, C. (1998). Doing a literature review: Releasing the social science research imagination. Sage Publications.

IFLA. (2012). IFLA Code of Ethics for Librarians and other Information Workers. IFLA Code of Ethics for Librarians and Other Information Workers. https://www.ifla.org/publications/node/11092 
Ireland, S. (2018). Fake news alerts: Teaching news literacy skills in a meme world. The Reference Librarian, 59(3), 122-128. https://doi.org/10.1080/02763877.2018.1463890

Kitchenham, B. (2004). Procedures for Performing Systematic Reviews. Keele University. http://www.inf.ufsc.br/ aldo.vw/kitchenham.pdf

LaPierre, S. S., \& Kitzie, V. (2019). "Lots of Questions about 'Fake News"': How Public Libraries Have Addressed Media Literacy, 2016-2018. Public Library Quarterly, 38(4), 428-452. https://doi.org/10.1080/01616846.2019.1600391

Liberati, A., Altman, D. G., Tetzlaff, J., Mulrow, C., Gøtzsche, P. C., Ioannidis, J. P. A., Clarke, M., Devereaux, P. J., Kleijnen, J., \& Moher, D. (2009). The PRISMA statement for reporting systematic reviews and meta-analyses of studies that evaluate healthcare interventions: Explanation and elaboration. BMJ, 339, b2700. https://doi.org/10.1136/bmj.b2700

Lim, S. (2020). Academic library guides for tackling fake news: A content analysis. The Journal of Academic Librarianship, 46(5), 102195. https://doi.org/10.1016/j.acalib.2020.102195

Lopez-Borrull, A., Vives-Gràcia, J., \& Badell, J.-I. (2018). Fake news, ¿amenaza u oportunidad para los profesionales de la información y la documentación? El Profesional de La Información, 27(6), 1346-1356. https://doi.org/10.3145/epi.2018.nov.17

Lor, P. J. (2018). Democracy, information, and libraries in a time of post-truth discourse. Library Management, 39(5), 307-321. https://doi.org/10.1108/LM-062017-0061

Lynch, K., \& Hunter, S. (2020). Conflicting authority: Using the Trump administration's responses to the EPA climate assessment report to teach information literacy. Reference Services Review, 48(1), 201-216. https://doi.org/10.1108/RSR-09-2019-0069

Mandalios, J. (2013). RADAR: An approach for helping students evaluate Internet sources. Journal of Information Science, 39(4), 470-478. https://doi.org/10.1177/0165551513478889

Martínez-Cardama, S., \& Algora-Cancho, L. (2019). Lucha contra la desinformación desde las bibliotecas universitarias. El Profesional de La Información, 28(4), e280412. https://doi.org/10.3145/epi.2019.jul.12

McIntyre, L. C. (2018). Post-truth. MIT Press.

Moher, D., Liberati, A., Tetzlaff, J., Altman, D. G., \& The PRISMA Group. (2009). Preferred Reporting Items for Systematic Reviews and Meta-Analyses: The PRISMA Statement. PLOS Medicine, 6(7), e1000097. https://doi.org/10.1371/journal.pmed.1000097

Musgrove, A. T., Powers, J. R., Rebar, L. C., \& Musgrove, G. J. (2018). Real or fake? Resources for teaching college students how to identify fake news. College \& Undergraduate Libraries, 25(3), 243-260. https://doi.org/10.1080/10691316.2018.1480444

Naeem, S. B., \& Bhatti, R. (2020). The Covid-19 'infodemic': A new front for information professionals. Health Information \& Libraries Journal, 37(3), 233239. https://doi.org/10.1111/hir.12311 
Neely-Sardon, A., \& Tignor, M. (2018). Focus on the facts: A news and information literacy instructional program. The Reference Librarian, 59(3), 108-121. https://doi.org/10.1080/02763877.2018.1468849

Niedringhaus, K. L. (2018). Information Literacy in a Fake/False News World: Why Does it Matter and How Does it Spread? International Journal of Legal Information, 46(2), 97-100. https://doi.org/10.1017/jli.2018.26

Pek, S., \& Wang, D. (2018). National Library Board's Public Education on Information Literacy: Teaching Citizens to Fight Fake News. Singapore Journal of Library and Information Management, 47, 2-14. https://www.las.org.sg/wp/sjlim/nlbpublic-education-on-information-literacy/

Peters, M. A., Rider, S., Hyvonen, M., \& Besley, T. (Eds.). (2018). Post-Truth, Fake News: Viral Modernity \& Higher Education. Springer.

Rana, M., \& O’Neill, S. (2020, October 16). Russians spread fake news over Oxford coronavirus vaccine. The Times. https://www.thetimes.co.uk/article/russiansspread-fake-news-over-oxford-coronavirus-vaccine-2nzpk8vrq

Rose-Wiles, L. (2018). Reflections on Fake News, Librarians, and Undergraduate Research. Reference \& User Services Quarterly, 57(3), 200-204. http://dx.doi.org/10.5860/rusq.57.3.6606

Rügenhagen, M., Beck, T. S., \& Sartorius, E. J. (2020). Information Integrity in the Era of Fake News: An Experiment Using Library Guidelines to Judge Information Integrity. Bibliothek Forschung Und Praxis, 44(1), 34-53. https://doi.org/10.1515/bfp-2020-0005

Saunders, L., \& Budd, J. (2020). Examining authority and reclaiming expertise. The Journal of Academic Librarianship, 46(1), 102077. https://doi.org/10.1016/j.acalib.2019.102077

Stapleton, J., Carter, C., \& Bredahl, L. (2020). Developing systematic search methods for the library literature: Methods and analysis. The Journal of Academic Librarianship, 46(5), 102190. https://doi.org/10.1016/j.acalib.2020.102190

Sullivan, M. (2019a). Libraries and Fake News: What's the Problem? What's the Plan? Communications in Information Literacy, 13(1), 91-113. https://doi.org/10.15760/comminfolit.2019.13.1.7

Sullivan, M. (2019b). Why librarians can't fight fake news. Journal of Librarianship and Information Science, 51(4), 1146-1156. https://doi.org/10.1177/0961000618764258

Sullivan, M. (2019c). Leveraging library trust to combat misinformation on social media. Library \& Information Science Research, 41(1), 2-10. https://doi.org/10.1016/j.lisr.2019.02.004

The CILIP Information Literacy Group. (2018). CILIP Definition of Information Literacy 2018. CILIP. https://infolit.org.uk/ILdefinitionCILIP2018.pdf

Wade, S., \& Hornick, J. (2018). Stop! Don't Share That Story!: Designing a Pop-Up Undergraduate Workshop on Fake News. The Reference Librarian, 59(4), 188194. https://doi.org/10.1080/02763877.2018.1498430

Yerbury, H., \& Henninger, M. (2018). Civil Commitment and the Role of Public Librarians. In S. Kurbanoğlu, J. Boustany, S. Špiranec, E. Grassian, D. Mizrachi, 
\& L. Roy (Eds.), Information Literacy in the Workplace (pp. 376-385). Springer International Publishing.

Zimdars, M., \& McLeod, K. (Eds.). (2020). Fake News: Understanding Media and Misinformation in the Digital Age. MIT Press. 